\title{
Холангіт як хірургічна проблема, оновлений погляд згідно з Токійськими клінічними рекомендаціями 2013 р. (TG 13)
}

\author{
M. YU. NYCHYTAYLO, A. I. HUTSULYAK, I. I. BULYK, M. S. ZAHRIICHUK, A. V. HOMAN \\ Shalimov National Institute of Surgery and Transplantology of NAMS of Ukraine
}

CHOLANGITIS AS A SURGICAL PROBLEM, NEW VIEW ACCORDING TO AN UPDATED TOKYO GUIDELINES 2013 (TG 13)

\begin{abstract}
У статті висвітлено проблему гострої біліарної інфекції, їі актуальність у хірургічній практиці на сьогодні, здійснено аналіз причин виникнення гострого холангіту та спектра інфекційних збудників, які призводять до його розвитку. Розглянуто сучасні класифікації та підходи до діагностики згідно з Токійськими клінічними рекомендаціями 2013 р. (TG13). Представлено комплексний підхід та алгоритм лікування гострого холангіту з врахуванням ступеня тяжкості захворювання, з відповідним моніторингом та корекцією терапії при зміні клінічної картини.

The article adduces the problem of acute biliary infection its importance in surgical practice to date has been described, the analysis of the causes of acute cholangitis and range of infections agents that lead to its development has been made. Modern classification and diagnostic approaches according to Tokyo Guidelines 2013 (TG13) are given. Comprehensive approach and treatment of acute cholangitis algorithm has been discussed, taking into account the stage of disease severity, appropriate monitoring and correction therapy in changing clinical picture.
\end{abstract}

Гостра біліарна інфекція включає в себе численні концепції різноманітних хвороб, але в основному представлена гострим холангітом, як системним інфекційним захворюванням, що часом може бути життєво небезпечним і потребувати негайного лікування, та гострим холециститом, зазвичай представленим помірною клінічною симптоматикою (блок-схема 1).

Гострий холангіт $(Г X)$ на даний час залишається актуальною проблемою в хірургії. Так, за даними різних авторів [1,2]:
- ГХ відмічається в 10-12 \% хворих на гострий холецистит, причому хворі похилого і старечого віку становлять $70 \%$;

- загострення ГХ після виконання холангіопанкреатографії складає $0,5-2,4 \%$;

- гнійний холангіт займає перше місце серед причин смерті після операцій на жовчних шляхах;

- рівень летальності від ГХ складає 2,7-10\%, досягаючи 40 \% при генералізації процесу у вигляді множинних холангіогенних абсцесів печінки та біліарного сепсису;

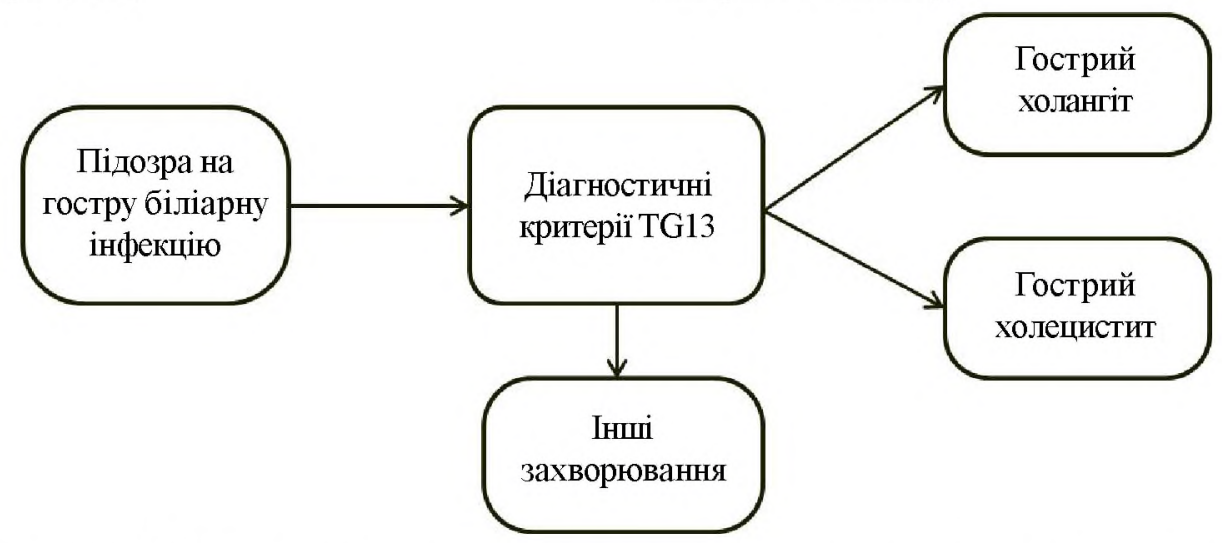

Блок-схема 1. Гостра біліарна інфекція в основному представлена гострим холангітом та гострим холециститом. 
- після ендоскопічних транспапілярних втручань через 2,5-15 років холангіт може рецидивувати в 7-47\% випадків;

- ГХ залишається найбільш тяжким ускладненням доброякісних та злоякісних стенозувальних захворювань жовчних шляхів та виникає в 15-93, 1 \% випадків;

- “гострий біліарний септичний” шок як наслідок транслокації мікроорганізмів із жовчі в системний кровообіг зустрічається у 10-30\% хворих з ГХ.

Для розвитку ГХ необхідні два фактори: порушення відтоку жовчі та іiї інфікування. Найбільш частими причинами обструкції жовчних проток $\epsilon$ холедохолітіаз, доброякісний стеноз, стриктури біліодигестивних анастомозів і злоякісний стеноз. Досить часто гнійний холангіт з абсцесами печінки розвивається після ятрогенного пошкодження жовчовивідних шляхів, під час операційних втручань на органах гепатопанкреатобіліарної зони. Так, внаслідок неадекватної декомпресії та наявності зовнішніх жовчних нориць гнійний холангіт виявляють у 2/3 хворих через 2-4 місяці після першої операції. Рідше ГХ розвивається як ускладнення холангіографії, ендоскопічної папілосфінктеротомії (ЕПСТ) чи після ендопротезування холедоха.

Позитивні результати посіву жовчі відзначаються у 80-100\% хворих з ГХ. Як правило, збудниками холангіту є мікроорганізми кишкової мікрофлори, які в більшості випадків зустрічаються в асоціаціях. До них належать представники сімейства ентеробактерій, серед яких домінуючу роль відіграє E. coli (50-60\%), з меншою частотою зустрічаються Klebsiella spp. (8-20\%), Serratia spp., Proteus spp., Enterobacter spp., Acinetobacter spp. Грампозитивні мікроорганізми Streptococcus, Enterococcus виявляються в 2-30 \% випадків, неспороутворюючі анаероби Bacteroides spp., Clostridium spp., фузобактерії, пептококи - до $20 \%$, Pseudomonas spp. - 2-4\% випадків [3, 4].

При гострому гнійному холангіті виявлено кореляцію між тяжкістю перебігу захворювання та характером мікрофлори. У хворих із вираженими явищами гнійної інтоксикації і тяжким ступенем печінкової недостатності в інфекційному процесі брали участь асоціації кишкової палички і бактероїдів, найбільш часто Bact. fragilis 3 високим ступенем

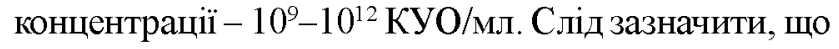
у 13-18\% хворих із типовою клінічною картиною ГХ мікробна флора з жовчі не висівається.

Зростання внутрішньопротокового тиску сприяє транслокації бактерій чи ендотоксинів у судинну i лімфатичну системи (холангіо-венозний/лімфатичний рефлюкс) і може призвести до тяжких ускладнень, таких як абсцеси печінки і біліарний сепсис.
3 того часу, як Charcot у 1887 р. вперше описав як “печінкову гарячку" хворобу пацієнта з тяжким ГХ, тріада Шарко широко використовується як один 3 найбільш важливих діагностичних критеріїв. I хоча для ГХ тріада Шарко показує дуже високу специфічність $(95,9 \%)$, але в зв'язку з низькою чутливістю $(26,4 \%)$ вона не може бути використана як критерій діагностики. В 2013 р. на основі даних, отриманих шляхом багатоцентрових досліджень, були представлені нові діагностичні критерії та критерії оцінки тяжкості, нові схеми лікування ГХ і холециститу, були додані нові дані та рекомендації для дренування жовчного міхура і жовчовивідних шляхів, а також хірургічних втручань Токійські клінічні рекомендації (TG13) [5]

Діагностичні критерії гострого холангіту

А. Системні ознаки запалення:

А-1 лихоманка $>38^{\circ} \mathrm{C}$ i/aбо озноби

А-2 лабораторні дані: Лей $(\times 1000 /$ мл $)<4$, або $>10$

$$
\mathrm{CP \Pi} \geq 1 \text { мг/дл }
$$

\section{В. Холестаз:}

В-1 жовтяниця (білірубін $\geq 2$ мг/дл (34,2 мкмоль/л))

В-2 лабораторні дані функціонального стану печінки (ЛФ, АлАТ, АсАТ, ГГТ (мОд) вище верхньої межі норми в 1,5 раза)

\section{С. Візуалізація:}

C-1 розширення жовчних проток

C-2 візуалізація причин холангіту - стриктури, камені

Ймовірний діагноз: один "+" пункт А та один "+" з В або C

Точний діагноз: один "+" пункт А, один “+" пункт В і один "+" С

3 інструментальних методів використовуються УЗД, КТ, МРПХГ. Вони не дають прямих даних, які свідчать про інфекцію в жовчних протоках, але дають змогу встановити діагноз ГХ, показуючи його непрямі ознаки, такі як розширення жовчних проток або причини виникнення: наявність у них конкрементів, пухлини чи стента. Необхідно проводити і УЗД, і КТ. Ці методи доповнюють один одного і дають можливість встановити наявність обтурації жовчних проток, її рівень і причину. На КТ краще видно розширення жовчних проток і пневмобілію. Ширші можливості відкриває використання спіральної КТ з динамічним контрастним посиленням.

За ступенями тяжкості перебігу гострий холангіт поділясться на:

Grade III (тяжкий ступінь) - наявність холангіту супроводжується порушенням однієї 3 таких систем:

1. Кардіоваскулярна дисфункція - гіпотензія, що вимагає введення дофаміну $\geq 5$ мг/кг за 1 хв або будь-які дози норадреналіну. 

мості.

2. Нейрологічні дисфункції - порушення свідо-

3. Респіраторні порушення $-\mathrm{PaO}_{2} / \mathrm{FiO}_{2}<300$

4. Ниркова дисфункція - олігурія, креатинін $>2,0$ мг/дл (177 мкмоль/л).

5. Печінкова дисфункція - ПЧ-МНО $>1,5$.

6. Гематологічні порушення - кількість тромбоцитів $<1000000 / \mathrm{MM}^{3}$.

Grade II (середній ступінь тяжкості) - наявність холангіту супроводжується двома 3 наступних показників:

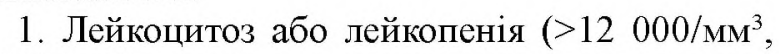
$\left.<4000 / \mathrm{MM}^{3}\right)$.

2. Висока температура $\left(\geq 39^{\circ} \mathrm{C}\right)$.

3. Вік (старший 75 років).

4. Гіпербілірубінемія (загальний білірубін $\geq 5$ мг/дл $(85,5$ мкмоль/л).

5. Гіпоальбумінемія $(<\mathrm{STD} \times 0,7)$

Grade I (легкий ступінь) - при встановленні первинного діагнозу ознаки не відповідають критеріям тяжкого або середнього ступенів холангіту [6].

Діагностичні критерії TG13 мають високу чутливість $(91,8 \%)$ та високу специфічність (77,7 \%). Вони дають можливість без затримки виконати дренування жовчних проток чи почати інше відповідне лікування. Базуючись на доведених даних, було встановлено п'ять факторів несприятливого прогнозу при ГХ - гіпербілірубінемію, високу температуpy, лейкоцитоз, літній вік пацієнта і гіпоальбумінемію. У пацієнтів, в яких наявні два 3 цих п'яти чинників, може бути встановлено середній ступінь тяжкості (Grade II) [6].
Двома найбільш важливими елементами лікування ГХ $є$ дренування жовчних проток і антибактеріальна терапія. Попереднє лікування включає внутрішньовенну інфузійну терапію, антибіотики, знеболювальні, ретельний моніторинг АТ, пульсу та сечовиділення. Одночасно необхідно провести оцінку ступеня тяжкості ГХ відповідно до критеріїв. Подальше лікування повинно проводитися відповідно до ступеня тяжкості (блок-схема 2). Обов'язковим $€$ проведення частої переоцінки і при необхідності повторної класифікації за ступенями Grade I, II і III, беручи до уваги відповідь на первинну медикаментозну терапію.

При ступені Grade I (легкий) в більшості випадків достатньо початкової терапії, яка включає антибактеріальні препарати. Дренування жовчних проток переважно не потрібне, його проводять тільки при відсутності ефекту від медикаментозної терапії. Лікування причини захворювання таким методом, як ЕПСТ при холедохолітіазі, по можливості проводять симультанно під час дренування жовчних проток. Деякі паціснти 3 післяопераційним холангітом потребують тільки антибактеріальної терапії без будь-якого операційного втручання.

При ступені Grade II (середньої тяжкості) необхідно виконати раннє біліарне дренування (ендоскопічне або черезшкірне дренування жовчних ходів або навіть термінове зовнішнє дренування холедоха Т-подібним дренажем). Остаточне лікування, відповідно до причини захворювання, проводять після покращення стану хворого та підготовки до операції.

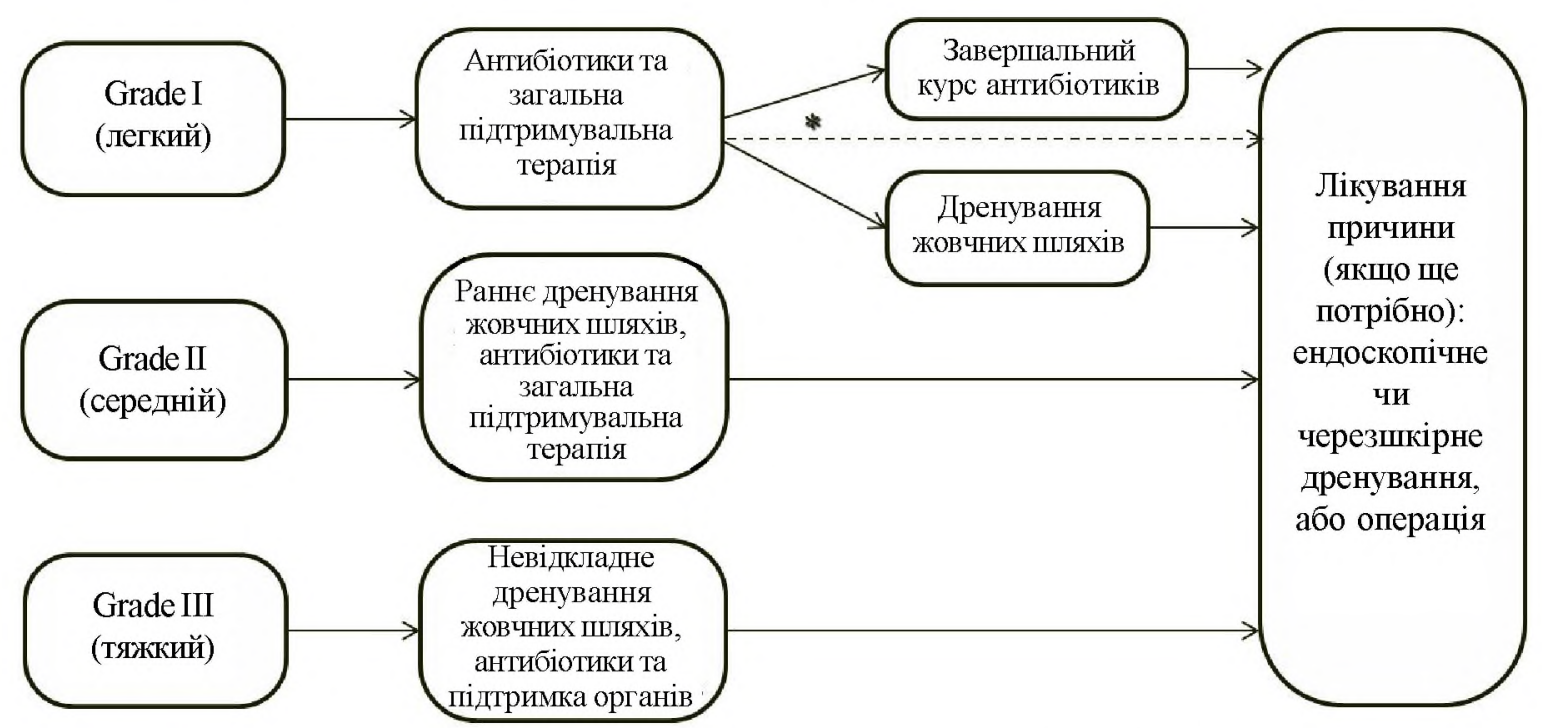

Блок-схема 2. Лікування гострого холангіту відповідно до ступеня тяжкості (Grade), клінічної відповіді на лікування та потреби подальшого лікування.

Примітка. * - у хворих з холедохолітіазом лікування по можливості повинно бути симультанним - усунення причини під час дренування жовчних шпляів. 
При ступені Grade III (тяжкий) на перше місце виступає органна дисфункція (гостра серцево-судинна, дихальна, ниркова, печінкова недостатність, ДВ3-синдром). Після стабілізації гемодинаміки виконують біліарне дренування (ендоскопічне, черезшкірне чи зовнішнє дренування Т-подібним дренажем). Остаточне лікування здійснюють після розрішення гостроти захворювання.

У TG 13 також розроблено алгоритм лікування

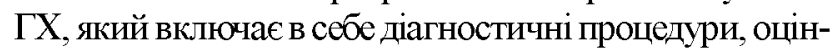
ку стану тяжкості хворого, транспортування пацієнта в разі необхідності в більш спеціалізовані лікувальні заходи, терапевтичні підходи та часовий контроль.

Алгоритм лікування при гострому холангіті

1. При підозрі на ГХ оцінку стану пацієнта згідно 3 діагностичними критеріями проводять кожні 612 год.

2. Спочатку проводять оглядову Rtg-графію та УЗД органів черевної порожнини, потім КТ, МРТ та МРПХГ.

3. Після встановлення діагнозу тяжкість стану пацієнта неодноразово повторно оцінюється протягом 24-48 год.

4. Одразу після встановлення діагнозу починають початкову терапію, яка включає: відновлення водно-електролітного балансу, знеболювання і антибіотики (в повній дозі).

5. При ГХ легкого ступеня, при відсутності ефекту від консервативної терапії протягом 24 год, негайно проводять дренування жовчних проток.

6. При середньому ступені тяжкості (Grade II) дренування жовчних проток проводять невідкладно одночасно $з$ початковою терапією. Якщо дренування не може бути здійснено через відсутність відповідних спеціалістів чи обладнання, тоді необхідно перевести пацієнта в лікувальний заклад, де $\epsilon$ можливість його виконати.

7. При тяжкому ступені (Grade III) дренування жовчних проток проводять після стабілізації стану хворого. Якщо дренування не може бути здійснено через відсутність відповідних спеціалістів чи обладнання, тоді необхідно перевести пацієнта в лікувальний заклад, де $\epsilon$ можливість його зробити.

8. При тяжкому ступені (Grade III) органопідтримувальну терапію (вентиляція легень, вазопресорна та антибактеріальна терапія) починають невідкладно.

9. При ступенях Grade II і Grade III необхідно провести визначення збудника в крові та жовчі.

10. Лікування причини ГХ шляхом ендоскопічного, черезшкірного чи операційного втручань проводять після розрішення гостроти захворювання. Холецистектомію при калькульозному холециститі виконують після розрішення гострого холангіту [7].
Біліарне дренування визнано основним методом лікування ГХ і рекомендовано незалежно від ступеня тяжкості, за винятком деяких випадків легкого перебігу (Grade I). Дренування жовчних шляхів поділяється на 3 типи: ендоскопічне, черезшкірне черезпечінкове та відкрите хірургічне. 3 цих видів перевагу віддають ендоскопічному дренуванню як найменш травматичному. При технічних труднощах виконують черезшкірне черезпечінкове дренування. Відкрите хірургічне дренування призводить до найбільшого рівня смертності і використовується вкрай рідко, при неможливості виконати дренування малоінвазивними методами.

Методом першочергового вибору є ендоскопічне транспапілярне дренування, яке вважають “"золотим стандартом" лікування, незалежно доброякісна чи злоякісна причина захворювання. Ендоскопічне транспапілярне біліарне дренування поділяють на 2 типи: ендоскопічне назобіліарне дренування (ЕНБД) (зовнішній тип дренування) та ендоскопічне біліарне стентування (ЕБС) (внутрішній тип дренування).

Виконання ендоскопічної папілотомії (ЕПСТ) перед ендоскопічним біліарним дренуванням повинно визначатися залежно від стану пацієнта та майстерності оператора. ЕПСТ із наступною холедохолітоекстракцією, без біліарного дренування, рекомендовано як альтернативну процедуру в паціснтів 3 холедохолітіазом.

Черезшкірний черезпечінковий біліарний дренаж (ЧЧБД) або черезшкірна черезпечінкова холангіостомія (ЧЧХС) є другочерговим методом дренування через можливі ускладнення, серед яких внутрішньочеревна кровотеча та жовчотеча. Цей метод виконують при обтурації верхніх відділів ШКТ, дуоденальній непрохідності, операціях з накладанням анастомозів на Ру-петлі, а також коли ендоскопічне дренування не вдається провести через технічні труднощі або відсутність у клініці кваліфікованого ендоскопіста. Відносним протипоказанням до ЧЧХС є коагулопатія. ЧЧХС є успішною у $86 \%$ пацієнтів із розширеними жовчними протоками і у $63 \%-3$ нерозширеними.

Антибактеріальна терапія $\epsilon$ важливим компонентом у лікуванні ГХ. На початковому етапі, до моменту ідентифікації збудника, вибір препарату рекомендовано проводити емпірично, з врахуванням ступеня тяжкості. Тривалість антибактеріальної терапії повинна становити 4-7 діб. Якщо є бактеріємія Enterococcus spp. i Streptococcus spp., рекомендована мінімальна тривалість - 2 тижні. Якщо зберігається резидуальний холедохолітіаз або обструкція жовчних проток, антибіотикотерапія повинна бути продовжена доти, доки причини обструкції не будуть усунуті [8]. 
Таким чином, у пацієнтів із ГХ, при несвосчасно наданій допомозі, відмічається високий ризик розвитку серйозних ускладнень, таких як холангіогенні абсцеси печінки та біліарний сепсис. Останні досягнення в розвитку та розповсюдженні ендоскопічного дренування жовчних проток разом $з$ призначенням антимікробних препаратів сприяли зниженню летальності

\section{СПИСОК ЛІТЕРАТУРИ}

1. Гейниц А. В. Лечение острого холангита / А. В. Гейниц, Н. А. Тогонидзе, М. С. Амаян // Анн. хирург. гепатол. -2003. T. 8, № 1. - C. 107-111.

2. Diagnostic criteria and severity assessment of acute cholangitis / K. Wada, T. Takada, Y. Kawarada [et al.] // Tokyo guidelines. 2007.

3. Rosh A. J. Cholangitis in Emergency Medicine / A. J. Rosh, B. E. Brenner // Medscape. - 2012.

4. Salvador V. Microbiology and antibiotic susceptibility of organisms in bile cultures from patients with and without cholangitis at an Asian Academic Medical Center / V. Salvador, M. Lozada, R. Consunji // Surg Infect. - 2011. - № 12. - P. 105-111.

5. TG13: Updated Tokyo Guidelines for the management of acute внаслідок ГХ. У хворих в тяжкому стані необхідно проводити консервативну терапію, а після стабілізації стану - декомпресію жовчних шляхів. Тим не менше, якщо раннс дренування жовчних проток не було проведено, дане захворювання залишається небезпечним для життя, негайна і точна оцінка тяжкості стану хворого мають першочергове значення.

cholangitis and cholecystitis / Tadahiro Takada, Steven M. Strasberg, Joseph S. Solomkin [et al.] // J. of HBP Sciences. 2014. - Vol. 20. - P. 1-7.

6. TG13 guidelines for diagnosis and severity grading of acute cholangitis / Seiki Kiriyama, Tadahiro Takada, Steven M. Strasber [et al.] // J. of HBP Sciences. - 2014. - Vol. 20. - P. 24-34.

7. TG13 management bundles for acute cholangitis and cholecystitis / Kohji Okamoto, Tadahiro Takada, Steven M. Strasberg [et al.] // J. of HBP Sciences. - 2014. - Vol. 20. - P. 5559.

8. TG13 antimicrobial therapy for acute cholangitis and cholecystitis / Harumi Gomi, Joseph S. Solomkin, Tadahiro Takada [et al.] // J. of HBP Sciences. - 2014. - Vol. 20. - P. 60-70. 